\title{
Faunal features of submarine canyons on the eastern Bering Sea slope
}

\author{
Michael F. Sigler ${ }^{1, *}$, Christopher N. Rooper ${ }^{2}$, Gerald R. Hoff ${ }^{2}$, Robert P. Stone ${ }^{1}$, \\ Robert A. McConnaughey ${ }^{2}$, Thomas K. Wilderbuer ${ }^{2}$
}

${ }^{1}$ NOAA Alaska Fisheries Science Center, 17109 Point Lena Loop Road, Juneau, Alaska 99801, USA

${ }^{2}$ NOAA Alaska Fisheries Science Center, 7600 Sand Point Way NE, Seattle, Washington 98115, USA

\begin{abstract}
Some of the largest submarine canyons in the world incise the eastern Bering Sea shelf break. Here, we examine whether 5 large canyons (Bering, Pribilof, Zhemchug, Pervenets and Navarin) are faunally distinct features within the eastern Bering Sea. We compiled data from the eastern Bering Sea that included trawl survey data on fish and invertebrate distributions and observations of ocean conditions and benthic habitat. These data were analyzed using multivariate techniques to determine if the canyons are distinguishable from the adjacent continental slope. We found that the 5 canyons are not faunally distinct features of the eastern Bering Sea slope but that the major characteristics structuring fish and invertebrate communities were depth, latitude and sediment rather than submarine canyons. One notable feature of these canyons is that about one quarter of the coral habitat predicted for the eastern Bering Sea slope occurs in Pribilof Canyon, an area that comprises only $\sim 10 \%$ of the total slope area. The predicted coral habitat also extends westward to the adjacent slope, indicating that this coral habitat concentration is not unique to Pribilof Canyon but rather that it is typical for a larger area (Pribilof Canyon and westward).
\end{abstract}

KEY WORDS: Eastern Bering Sea slope $\cdot$ Canyons $\cdot$ Habitat $\cdot$ Fish $\cdot$ Coral $\cdot$ Sponge

\section{INTRODUCTION}

The eastern Bering Sea slope and outer shelf is a region of enhanced primary and secondary productivity (the 'Bering Sea Greenbelt') and attracts large numbers of fish, seabirds and marine mammals; productivity is enhanced because of physical processes at the shelf break. These include intensive tidal mixing and transverse circulation and eddies in the Bering Slope Current which bring nutrients into the photic zone (Springer et al. 1996). About $40 \%$ of US commercial fisheries catch originates from the eastern Bering Sea; some of these fisheries concentrate on the slope and outer shelf. Five large submarine canyons (Bering, Pribilof, Zhemchug, Pervenets and Navarin canyons) incise the eastern Bering Sea shelf break (Fig. 1) (Karl et al. 1996, Normarck \& Carlson 2003) and are dominant geological features on the shelf break. These eastern Bering Sea canyons are 5 of an estimated 290 submarine canyons found along the western coast of North America; these 290 canyons are spaced an average of 30 to $35 \mathrm{~km}$ apart (Harris \& Whiteway 2011) and interrupt roughly $20 \%$ of the shelf edge between Alaska and the Equator (Hickey 1995).

The seafloor gradients (slopes) and shapes of the 5 eastern Bering Sea canyons differ from one another. Navarin (total volume $=5400 \mathrm{~km}^{3}$ ) and Pervenets $\left(1700 \mathrm{~km}^{3}\right)$ canyons resemble gently sloping amphitheaters; Zhemchug $\left(5800 \mathrm{~km}^{3}\right)$ and Pribilof $\left(1300 \mathrm{~km}^{3}\right)$ canyons are steeper and elongate parallel to the shelf edge; Bering Canyon $\left(4300 \mathrm{~km}^{3}\right)$ is V-shaped and gradually widens downslope (Karl et al. 1996). Two other large canyons, St. Matthew $\left(740 \mathrm{~km}^{3}\right)$ and Middle $\left(1800 \mathrm{~km}^{3}\right)$, lie along the eastern Bering Sea outer shelf, but barely indent the shelf break (Karl et al. 


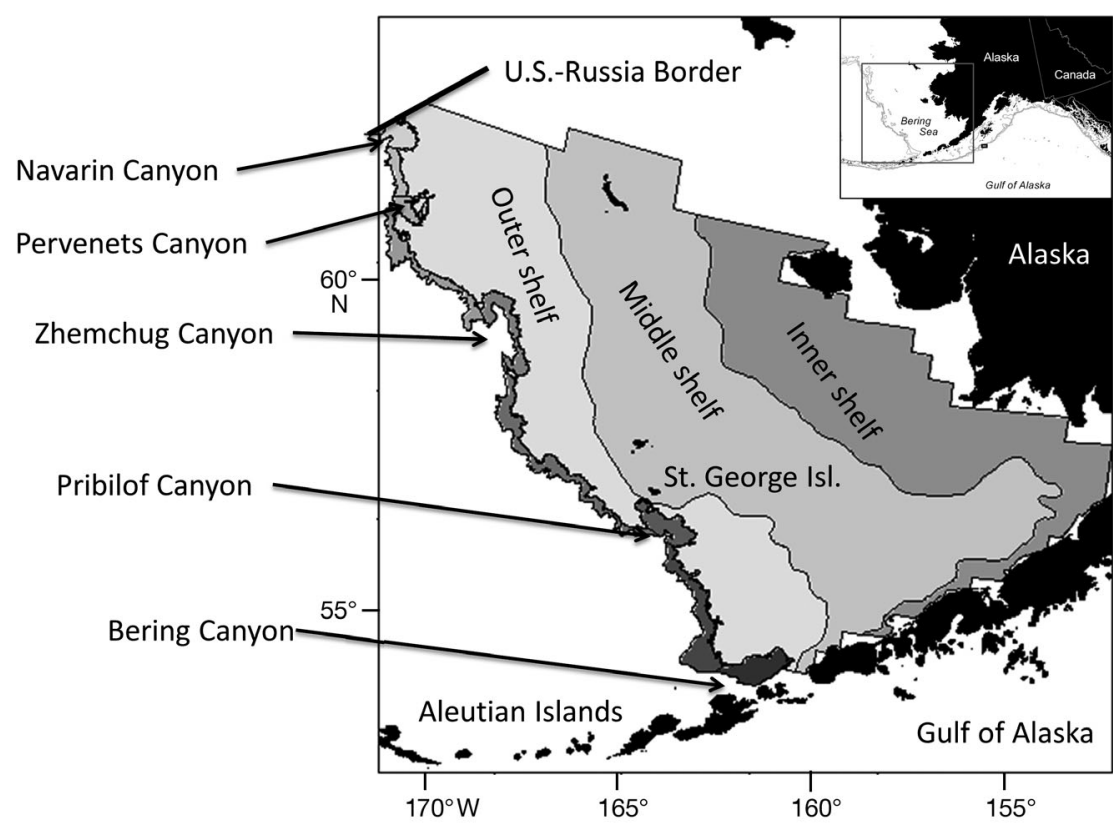

Fig. 1. Some of the largest submarine canyons in the world incise the eastern Bering Sea shelf break including Bering, Pribilof, Zhemchug, Pervenets and Navarin canyons. The boundaries of the shelf areas are based on depth (inner: $<50 \mathrm{~m}$; middle: 50-100 m) except that the shelf break (as defined in

'Materials and methods') is the seaward boundary of the outer shelf
Transport across the shelf break (both on-shelf and off-shelf) is also influenced by seasonal patterns in wind direction (Danielson et al. 2012). Although onshelf transport may occur virtually anywhere along the shelf break, preferential transport onto the shelf has been observed at Bering Canyon and west of the Pribilof Islands (Stabeno et al. 1999). At Bering Canyon, which lies along the Aleutian Islands near Unimak Pass, Aleutian North Slope Current waters interact with canyon topography and come onto the shelf (Schumacher \& Stabeno 1998). West of the Pribilof Islands, the outer shelf narrows south of St. George Island, accelerating the flow, which then turns northward, becomes shallower and parallels the $100 \mathrm{~m}$ contour west of the Pribilof Islands (Stabeno et al. 2008).

Concentrations of rockfish (Brodeur 2001, Rooper et al. 2010) and corals and sponges (Miller et al. 2012) have been found in Pribilof and Zhemchug canyons. Skates (Rajidae) deposit their 1996). The continental slope of the eastern Bering Sea descends from the shelf break to an average depth of $\sim 3000 \mathrm{~m}$; the gradient of the slope averages $5^{\circ}$ and ranges from $3^{\circ}$ to $8^{\circ}$ (Karl et al. 1996). The main channels of these large canyons all reach the base of the continental slope (i.e. average depth of $\sim 3000$ m) (Karl et al. 1996).

Canyons that indent the shelf break can interrupt along-slope currents and thus may create unique physical environments in canyons compared to the adjacent slope. The Bering Slope Current flows northwest along the slope of the eastern Bering Sea (Stabeno et al. 1999) with moderate flow (2 to $18 \mathrm{~cm}$ $\mathrm{s}^{-1}$ ) following the bathymetry and existing primarily in the upper $300 \mathrm{~m}$ (Schumacher \& Reed 1992). Eddies ranging in size from 40 to $150 \mathrm{~km}$ may be imbedded in the flow (Stabeno et al. 1999). Earlier research found that these eddies transit parallel to the continental slope and are not tied to the canyons (Schumacher \& Stabeno 1994). However, recent research has found that these canyons appear to be more prone to eddy activity and associated with higher rates of on-shelf transport of deep-basin water (Clement Kinney et al. 2009); eddy activity in the eastern Bering Sea is particularly strong near the major shelf-break canyons during the spring months, likely influencing the spring bloom (Ladd et al. 2012). large leathery egg cases in specific areas; 10 of 14 identified nursery sites are at the heads of the 5 large canyons (Navarin: 1; Pervenets: 3; Zhemchug: 2; Pribilof: 2; Bering: 2) with the other 4 sites at the heads of smaller deeper canyons (Hoff 2010). The strong association with canyons is believed to be correlated with oceanographic conditions such as bottom currents, oxygen content and productivity, but is still being investigated (G. R. Hoff pers. obs.). The spawning locations of walleye pollock, the target of the largest commercial fishery in the USA (by weight), are not uniquely associated with any eastern Bering Sea canyon (Bacheler et al. 2012); a spawning concentration that occurs around the Pribilof Islands (Bacheler et al. 2010) is not limited to Pribilof Canyon. are features within the eastern Bering Sea slope which are distinguishable by distinct physical and oceanographic characteristics (such as bottom temperature, seafloor gradient and sediment type) or by distinct biological characteristics (such as presence of coral and sponge). Our analyses are based on information collected during standard bottom trawl surveys, the only data source which covers most of the eastern Bering Sea slope. Bottom trawls are imperfect samplers for deep-sea corals and sponges,
In this paper, we assess whether these 5 canyons 
and sampling efficiency is taxa- and size-specific (Wassenberg et al. 2002, Mortensen et al. 2008, Auster et al. 2011). Despite these limitations, research trawl catches are often the only information available on species distribution and as a result, information from trawl surveys is used to model the distributions of deep-sea corals and sponges (Kenchington et al. 2010, 2013, Murillo et al. 2012, Knudby et al. 2013, Rooper et al. 2014), which is the approach that we take in this study.

\section{MATERIALS AND METHODS}

\section{Data}

Independent variables for our analyses included 7 environmental variables (bathymetry, seafloor gradient, sediment grain size, sediment sorting, bottom temperature, ocean current and ocean color). The available information for each variable was interpolated (specific methods follow) and the resulting raster layers were projected into Alaska Albers Equal Area Conic projection (center latitude: $50^{\circ} \mathrm{N}$, center longitude: $154^{\circ} \mathrm{W}$ ) and degrees of latitude and longitude were transformed into $1 \times 1 \mathrm{~km}$ square grids of eastings and northings for modeling (hereafter 'standard grid'). For bathymetry, depth soundings from US National Ocean Service (NOS) surveys (digitized 'smooth sheets') were transformed to the scale of the standard grid using inverse distance weighting implemented in ArcGIS software (ESRI 2009). Maximum seafloor gradient at each grid cell (the maximum depth difference between each cell and the adjacent 8 cells) was computed using the Spatial Analyst package in ArcGIS. Two measurements of sediment type from the Eastern Bering Sea Sediment Database (EBSSED) were used in these analyses: sediment grain size and sediment sorting (Smith \& McConnaughey 1999; National Geophysical Data Center Seafloor Sediment Grain Size database, ngdc. noaa.gov/geosamples/metadata.jsp?g=G00127).

Mean grain size (mm) is expressed as 'phi', which is negative $\log _{2}$-transform of grain size (e.g. large 'phi' indicates fine grains). Sediment sorting is defined as the standard deviation of phi in each sediment sample. The sampling tools for this sediment information are bottom grabs and corers, which do not distinguish boulder or bedrock habitat, and as a result, these habitat types are implicitly excluded from our analysis. The grain size and sorting values from the sediment data $(\mathrm{n}=803)$ were kriged using an exponential model (Venables \& Ripley 2002), which was the best fit to the semi-variogram of both grain size and sorting values.

Measurements of bottom temperature $(n=1371)$ collected during standard bottom trawl surveys (Hoff \& Britt 2013, Lauth 2013) were kriged using a spherical semi-variance model; the resulting grid represents the long-term average of summer conditions in the eastern Bering Sea since 1996. Values from a model-based reconstruction of ocean currents from 1975 to 2010 on a $10 \times 10 \mathrm{~km}$ grid (Northeast Pacific [NEP] 'Regional Ocean Modeling System' [ROMS]) (Danielson et al. 2011) were averaged because longterm current patterns likely influence the spatial distributions of corals and sponges. Monthly averages (May-September from 2003-2011) of satellite-based measurements of ocean productivity (ocean color) on a $11.9 \times 18.5 \mathrm{~km}$ grid (MODIS, Behrenfeld \& Falkowski [1997], www.science.oregonstate.edu/ ocean.productivity/) were averaged for each grid cell across months within each year and then averaged across all years. We averaged over all years rather than taking annual values because months were often poorly sampled or not sampled due to cloud cover. The average values of currents and productivity were interpolated using inverse distance weighting because these data were available on a regular grid and there was no indication of non-random spatial structure for either data set in semi-variogram plots.

The data on fauna used for these analyses were collected during 2 different, standard bottom trawl surveys of the eastern Bering Sea (Hoff \& Britt 2013, Lauth 2013). The data from the 2 surveys were combined, although not all data were used in all analyses, as will be described in the next 2 sub-sections. Depths from 30 to $200 \mathrm{~m}$ have been sampled annually since 1982 and depths from 200 to 1200 m have been sampled biennially since 2002 (with a gap in 2006). These data are the only routinely collected data for fish and invertebrates (e.g. coral) that systematically sample most of the eastern Bering Sea. They cover the upper continental slope (depths up to $1200 \mathrm{~m}$ ), but not the lower continental slope which extends to $\sim 3000 \mathrm{~m}$. The 2 surveys are identical in some ways. Trawl tows were conducted for $30 \mathrm{~min}$. Bottom contact and net dimensions were recorded throughout each trawl using net mensuration equipment. For these analyses, data were only used if trawl performance was satisfactory and if the distance fished, geographic position, and depth were recorded. However the 2 surveys differ in 3 important ways (net type, towing speed and survey design); this was necessary because of the differences in the habitats sampled. A 
trawl without roller gear was towed at a target speed of $5.6 \mathrm{~km} \mathrm{~h}^{-1}$ to sample depths from 30 to $200 \mathrm{~m}$ which are mostly flat and smooth, whereas a trawl with roller gear was towed at a target speed of $4.6 \mathrm{~km}$ $\mathrm{h}^{-1}$ to sample depths from 200 to $1200 \mathrm{~m}$ which are sloped and sometimes irregular. The roller gear reduces the occurrence of net hangs on irregular seafloor. The trawl without roller gear is an 83-112 Eastern low-opening $(2.5 \mathrm{~m})$ trawl with $34.1 \mathrm{~m}$ footrope (Lauth 2013). The trawl with roller gear is a poly Nor'Eastern high-opening $(7 \mathrm{~m})$ trawl with $24.2 \mathrm{~m}$ roller gear constructed with $36 \mathrm{~cm}$ rubber bobbins separated by $10 \mathrm{~cm}$ rubber disks (Hoff \& Britt 2013). A systematic $37 \times 37 \mathrm{~km}$ grid was used to sample depths from 30 to $200 \mathrm{~m}$, whereas a stratified random design was used to sample depths from 200 to 1200 m (Hoff \& Britt 2013, Lauth 2013). A systematic grid, which is unusual for fisheries surveys, was used because the seafloor for depths 30 to $200 \mathrm{~m}$ is flat and broad. Differences in the net type, but not the survey design, likely affect some of the data. The roller gear raises the net footrope off the seafloor so small corals and sponges and small fish on the bottom likely are more readily caught by the net without roller gear.

We analyzed data for 2002, 2004, 2008, 2010 and 2012, when both surveys took place ( $\mathrm{n}=1381$ trawl hauls, Table 1). During these surveys, all fish and invertebrates captured during a trawl haul were sorted to the lowest taxonomic level practical, typically species, and the total weight by species in the catch was determined. Catch per unit effort (CPUE, $\mathrm{kg} \mathrm{ha}{ }^{-1}$ ) for each taxonomic group and trawl haul was calculated by dividing catch in weight by area swept (the product of net width and distance towed).

Table 1. Number of trawl survey tows by area and year. BeringPribilof, Pribilof-Zhemchung etc. are inter-canyon areas

\begin{tabular}{|lcccccc|}
\hline \multirow{2}{*}{ Area name } & \multicolumn{7}{c}{ Survey year } & \multirow{2}{*}{ Total } \\
& 2002 & 2004 & 2008 & 2010 & 2012 & \\
\hline Bering Canyon & 11 & 28 & 21 & 22 & 14 & 96 \\
Bering-Pribilof & 26 & 42 & 35 & 24 & 31 & 158 \\
Pribilof Canyon & 7 & 16 & 13 & 15 & 9 & 60 \\
Pribilof-Zhemchug & 24 & 31 & 31 & 29 & 27 & 142 \\
Zhemchug Canyon & 13 & 16 & 16 & 16 & 15 & 76 \\
Zhemchug-Pervenets & 17 & 22 & 18 & 18 & 19 & 94 \\
Pervenets Canyon & 6 & 7 & 9 & 7 & 12 & 41 \\
Pervenets-Navarin & 6 & 10 & 7 & 10 & 12 & 45 \\
Navarin Canyon & 7 & 11 & 14 & 11 & 10 & 53 \\
Total slope stations & 117 & 183 & 164 & 152 & 149 & 765 \\
Total outer shelf stations & 113 & 131 & 119 & 133 & 120 & 616 \\
& & & & & & \\
\hline
\end{tabular}

\section{Multivariate analyses of physical habitat}

We define 3 major physical habitats in our analysis: canyon and non-canyon slope and the outer continental shelf (Fig. 1). The shoreward boundary of the outer shelf is based on the usual location of an oceanic front during summer (100 m) (Coachman 1986). The geological boundary between the continental shelf and slope, the shelf break, was defined as a prominent change in seafloor gradient from low to steeper (D. W. Scholl pers. comm.). Contours of $0.5,1,2,3$ and $5 \%$ on the seafloor gradient map showed that a prominent change occurred at $1 \%$, which we defined as the shelf-slope boundary. This shelf-slope boundary typically lies at $\sim 200 \mathrm{~m}$, except for the northern edge of Bering Canyon and the adjacent slope where it lies at $\sim 500 \mathrm{~m}$. The canyon lateral boundaries were located at the closest ridge crest on either side of the canyon axis (H. G. Greene pers. comm.). We considered the 5 large canyons that intersect the eastern Bering Sea shelf break (Navarin, Pervenets, Bering, Pribilof and Zhemchug), but not the 2 canyons, St. Matthew and Middle canyons, that barely indent the shelf break (Karl et al. 1996).

Multivariate analyses were applied to determine whether physical habitat characteristics differ among the 5 large canyons and the 4 slope areas lying between them, a total of 9 areas. For each trawl survey location, we extracted the associated habitat information (e.g. water temperature) from the 7 raster layers. Because these multivariate analyses focused on comparing canyons to slope areas lying between the canyons, they examined only data from the slope (the number of trawl survey locations on the slope was 765) (Table 1). A non-metric multidimensional scaling (NMDS) analysis graphically examined whether the 9 areas were easily distinguishable and, if so, what factors were associated with these differences. NMDS produces a value termed 'stress'; stress values $>0.3$ indicate the configuration is no better than arbitrary, and we should not try and interpret configurations unless stress values are $<0.2$, and ideally $<0.1$ (Clarke 1993). Euclidean distance was used for the NMDS. An analysis of similarity (ANOSIM) tested for statistically significant differences in the rank order of dissimilarity values for the 9 areas; the dissimilarity matrix was computed from the habitat variables. ANOSIM produces an R-value, which is a test statistic that varies between -1 and 1 , and a proba- 
bility based on random permutation of the groupings. An R-value of 0 indicates random assignment of the data into groups, while an R-value of 1 indicates perfect discrimination between groups was obtained. The threshold for statistical significance is usually $\mathrm{p}<$ 0.05 , but with large sample sizes such as ours, interpretation must consider the R-value; an R-value close to zero can indicate that the relationship is not meaningful, even if $p<0.05$. A quadratic discriminant function analysis (DFA) tested the classification of stations into the 9 areas and measured how well group membership was predicted for each area using an optimal combination of quadratic functions. Station groupings were determined using leave-one-out cross-validation. The percentage agreement between the observed and predicted classifications indicated how well areas were discriminated. The NMDS, ANOSIM and DFA were completed using the stats, MASS and vegan packages implemented in R statistical software (Venables \& Ripley 2002, Oksanen et al. 2013, R Core Team 2013). The data were first standardized to remove the effect of scale differences among physical habitat variables (e.g. temperature and depth are measured on different scales) for these analyses. For NMDS, the values were first square-root transformed (a transformation was necessary for NMDS to converge) and were then standardized on the range $[0,1]$ by dividing by the maximum value for each data set. For ANOSIM and DFA, the data were standardized (to mean $=0$ and $\mathrm{SD}=1$ ) by subtracting the mean and dividing by the standard deviation.

\section{Multivariate analyses of fauna}

Multivariate analyses were applied to determine whether fauna differ among the 5 large canyons and the 4 slope areas lying between the canyons. Our approach was to examine ecologically important species with importance based on density $\left(\mathrm{kg} \mathrm{ha}^{-1}\right)$. For the multivariate analysis, we included the top 20 species of fish (19) and crab (1) captured. For structureforming benthic invertebrates (corals and sponges), positive catches were few for some taxa, so we pooled taxa into family (Plexauridae, Primnoidae, Isididae, Paragorgiidae and Pennatulacea) or order (Antipatharia) groups for coral, and combined sponge taxa into 1 group (Porifera). The fish and crab species were analyzed together, but separately from the structure-forming benthic invertebrates.

We applied a similar multivariate analysis approach (i.e. NMDS, ANOSIM, DFA) to the fauna information as was applied to the physical habitat information. For NMDS, we tested second and fourth root transformations (Clarke 1993) and chose fourth root based on the stress value, NMDS convergence and NMDS axes plot. For ANOSIM and DFA, the catch data were $\log _{\mathrm{e}}$ (+ constant) transformed prior to analysis. The constant used for each species was one-half of the minimum positive catch $(>0)$ for that species. Like the multivariate analyses of physical habitat data, these multivariate analyses of fauna data focused on comparing canyons to slope areas lying between the canyons and examined only data from the slope (i.e. $\mathrm{n}=765)$, nearly all (>99\%) collected by the trawl with roller gear.

\section{Distribution and habitat modeling}

We also modeled the spatial distribution of fauna. For this modeling, data from the outer shelf area were added to provide more complete spatial coverage of taxa (the number of trawl survey locations on the outer shelf was 616) (Table 1). The distributions of the top 20 taxa of fish and crab were modeled. Since catches of structure-forming invertebrates were generally uncommon (particularly for coral species), corals were grouped to family (Plexauridae, Primnoidae, Isididae and Paragorgiidae) or order (Antipatharia) and hereafter referred to as 'corals', with a separate grouping for sea pens and sea whips (Pennatulacea, hereafter 'sea whips'). Sponges (Porifera) were modeled as a group.

We applied generalized additive modeling (GAM, Hastie \& Tibshirani 1990) fit using the mgcv package in R (Wood 2006) to construct relationships between habitat variables of location (latitude and longitude), depth, temperature, seafloor gradient, current speed, ocean productivity, grain size and sediment sorting, and the $\log _{\mathrm{e}}$-transformed density (LCPUE, $\mathrm{kg} \mathrm{ha}^{-1}$ ) of the fish and crab species, as well as between the same habitat variables (e.g. location) and the presence-absence of coral, sponge and sea whips. For the latter 3 taxa, presenceabsence was used instead of density because the large number of zero catches and high variability in positive catches made it difficult to model an appropriate error distribution. There was some collinearity in the habitat variables included in the model, but all had $\mathrm{R}^{2}<0.66$ and most $(86 \%)$ were not well correlated $\left(\mathrm{R}^{2}<0.22\right)$. In addition, variance inflation factors were calculated using the method of Zuur et al. (2009), resulting in values ranging from 1.2 to 3.6 for the habitat variables (except 
the bivariate term location). These values were all acceptable $(<5.0)$ allowing inclusion of these variables in the modeling in their univariate form. During initial analyses, a number of distribution combinations and data transformations were explored to use with the CPUE data, including the Gaussian (Wood 2006) and Gamma (Wood 2006) and both the second and fourth root transformations. The $\log _{\mathrm{e}}$ transformation with constants of $1,10 \%$ of the mean CPUE and half of the smallest positive value also were evaluated. Residuals from each distribution and data transformation were visually compared to the normal distribution using quantilequantile plots to determine which combination best approximated normality for each response variable. The Gaussian distribution with $\log _{\mathrm{e}}$-transformed CPUE data and a constant of half of the smallest positive value proved to best approximate normality for the analyses of CPUE data. The binomial distribution was determined to best fit the presenceabsence data. Our approach was similar to other recent predictive modeling of coral distribution (Woodby et al. 2009, Ross \& Howell 2013, Rooper et al. 2014).

Backward selection was used to determine the best-fitting model for each taxa, where the full model containing all variables was fit to the data, the least significant variable was eliminated and the model was refit until no further gain in the generalized cross-validation (GCV) criterion (Wood 2006) was attained. Model overfitting was reduced by limiting the basis degrees of freedom to $\leq 4$ for univariate variables and $\leq 30$ for the bivariate term (location). Presence models were compared using the unbiased risk estimator (UBRE) criterion (Wood 2006). For LCPUE data the scale parameter was estimated from the data and for presence-absence data the scale was one. Maps of species distributions were produced by applying the best-fitting GAM to the raster layers of habitat variables to predict probability of presence (for coral, sponge and sea whips) or density (for fishes and crab) at each raster cell.

The accuracy of the models using LCPUE data was evaluated by comparing the model predictions to the observations using the squared Pearson correlation coefficient. The accuracy of the presenceabsence models was evaluated by 2 methods. For the first method, the area under the receiver operating curve (AUC) was computed, which is the probability that a randomly chosen presence observation would have a higher probability of presence than a randomly chosen absence observation using rank data. We used the scale of Hosmer \& Lemeshow
(2004), where an AUC value $>0.5$ is better than chance, a value $>0.7$ is acceptable, and values $>0.8$ and 0.9 are excellent and outstanding, respectively. For the second method, probability of presence was categorized into either present or absent using a threshold probability value. The categorization could be biased towards absence (Hosmer \& Lemeshow 2004) because the data contained many more absences than presences. Thresholds were chosen empirically to balance the number of false positives and false negatives and ranged from 0.27 to 0.53 depending on the data set. Cohen's Kappa (Fielding \& Bell 1997) was computed from the resulting confusion matrix.

\section{RESULTS}

\section{Physical habitat}

The eastern Bering Sea is characterized by a broad, flat shelf bordered by a shallow-gradient slope; most $(90 \%)$ of the slope has a $10 \%$ gradient or less (Table 2). The steepest canyons are Pribilof and Zhemchug canyons, yet most of their habitat has a gradient of $11 \%$ or less. The steepest inter-canyon area is Pribilof-Zhemchug (17\% or less). The maximum seafloor gradient of any grid cell is $67 \%$, in Pribilof-Zhemchug; the maximum for any canyon grid cell occurs in Pribilof Canyon (50\%). Canyons comprise almost half $(43 \%)$ of the total seafloor area of the eastern Bering Sea slope, with the remainder (57\%) being inter-canyon areas (Table 2).

The NMDS of physical habitat variables showed that the first NMDS axis was highly correlated with ocean productivity and current speed, and the second axis with depth and temperature (Table 3). Individual areas clustered together in the NMDS plot (e.g. Bering Canyon samples) (Fig. 2). The cluster for each individual area stretched parallel to the depthtemperature axis, reflecting the within-area depth range of $150-1200 \mathrm{~m}$. Areas separated from north to south parallel to the ocean productivity-current speed axis and adjacent areas overlapped somewhat. The corresponding ANOSIM showed a significant result ( $R=0.54, p=0.001)$. For the DFA, the percentage of stations correctly classified into an area ranged from $91 \%$ for Pervenets-Navarin to $100 \%$ correct for Bering-Pribilof, Pribilof Canyon, Pribilof-Zhemchug and Navarin Canyon (Table 4). Both the significant result for the ANOSIM and the highly predictable group membership for the DFA are consistent with the separation of individual areas in the NMDS. 


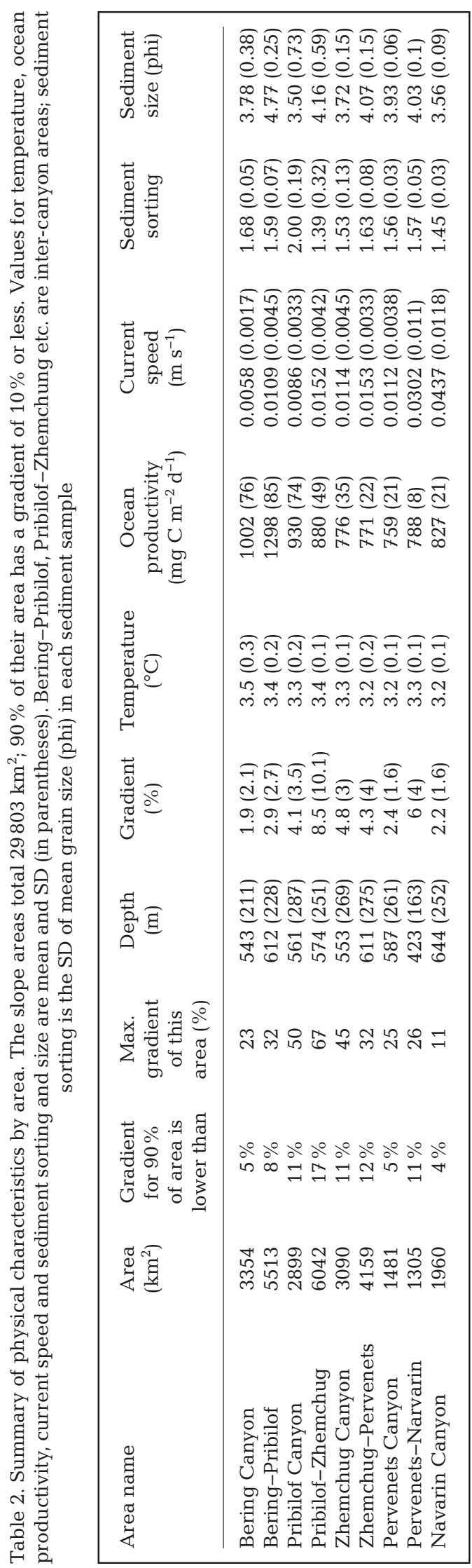

Table 3. Correlations for the first 2 axes of the non-metric multidimensional scaling (NMDS) of the physical and biota variables. CPUE: catch per unit effort

\begin{tabular}{|c|c|c|}
\hline Dataset/Variable & NMDS1 & NMDS2 \\
\hline \multicolumn{3}{|l|}{ Physical habitat } \\
\hline Depth & 0.160 & 0.948 \\
\hline Gradient & -0.446 & 0.261 \\
\hline Avg. temperature & 0.099 & -0.604 \\
\hline Ocean productivity & 0.511 & 0.155 \\
\hline Current speed & -0.913 & 0.053 \\
\hline Sediment sorting & 0.280 & -0.128 \\
\hline Sediment size & 0.192 & 0.212 \\
\hline \multicolumn{3}{|l|}{ Fish CPUE } \\
\hline Sleeper shark & -0.058 & -0.101 \\
\hline Commander skate & 0.368 & 0.098 \\
\hline Eelpout & 0.140 & -0.575 \\
\hline Rex sole & -0.771 & 0.098 \\
\hline Tanner crab & 0.596 & -0.104 \\
\hline Alaska skate & -0.458 & 0.040 \\
\hline Aleutian skate & -0.345 & -0.071 \\
\hline Arrowtooth flounder & -0.803 & -0.007 \\
\hline Kamchatka flounder & -0.370 & -0.490 \\
\hline Greenland turbot & 0.093 & -0.599 \\
\hline Pacific halibut & -0.493 & -0.050 \\
\hline Flathead sole & -0.723 & 0.032 \\
\hline Sablefish & 0.396 & -0.533 \\
\hline Giant grenadier & 0.802 & 0.183 \\
\hline Pacific grenadier & 0.545 & 0.289 \\
\hline Pacific cod & -0.717 & 0.326 \\
\hline Shortraker rockfish & -0.244 & 0.215 \\
\hline Pacific ocean perch & -0.669 & 0.340 \\
\hline Walleye pollock & -0.729 & 0.040 \\
\hline Shortspine thornyhead & 0.240 & -0.465 \\
\hline \multicolumn{3}{|l|}{ Invertebrate CPUE } \\
\hline Porifera & 0.998 & -0.027 \\
\hline Paragorgiidae & 0.105 & 0.811 \\
\hline Plexauridae & 0.092 & 0.023 \\
\hline Primnoidae & 0.268 & 0.326 \\
\hline Antipatharia & 0.018 & 0.315 \\
\hline Pennatulacea & -0.083 & -0.420 \\
\hline Isididae & 0.142 & 0.644 \\
\hline
\end{tabular}

\section{Fauna}

The NMDS of the fish and crab species showed that the first NMDS axis was negatively correlated with shallower species, such as Pacific cod, walleye pollock and Pacific ocean perch, and positively correlated with deeper species, such as Pacific grenadier and giant grenadier, whereas the second NMDS axis was negatively correlated with species that were more common southward, such as sablefish and eelpout (Table 3). The 9 areas overlapped in the NMDS plot (Fig. 3). The corresponding ANOSIM was significant $(R=0.388, p=0.001)$, suggesting incomplete overlap among the 9 areas in the NMDS plot. Using DFA, group membership in individual areas was much less predictable for fish and crab species 


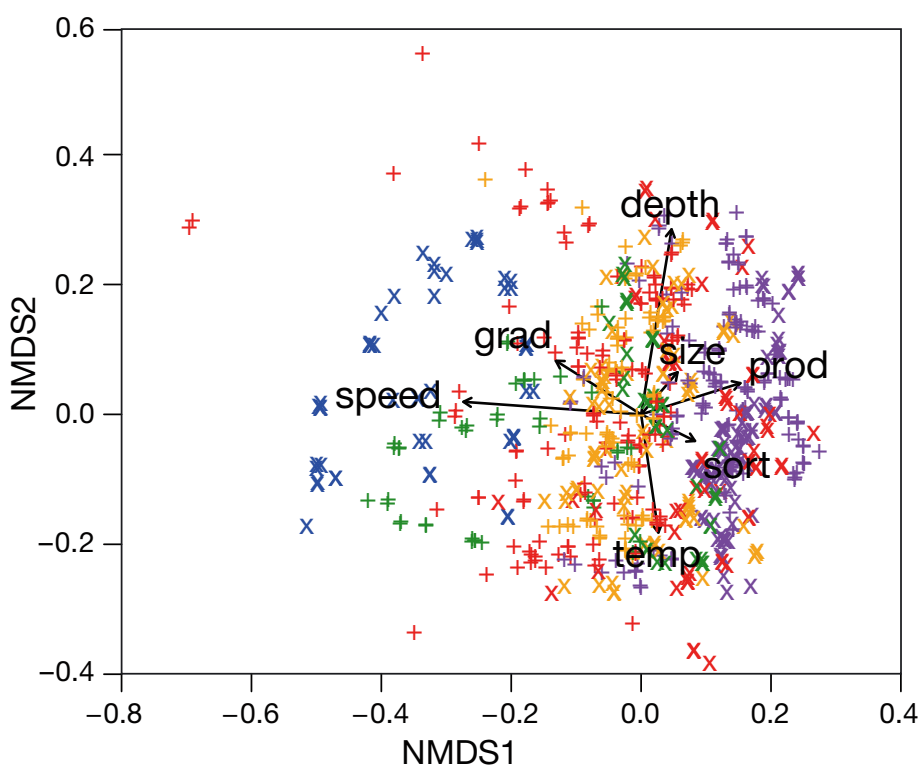

Fig. 2. Plot of major non-metric multidimentional scaling (NMDS) axes of physical data. The variables are depth, temperature (temp), gradient (grad), productivity color (prod), current speed (speed), and sediment size (size) and sorting (sort). (X) Bering Canyon; (+) Bering-Pribilof inter-canyon area; (x) Pribilof Canyon; (+) Pribilof-Zhemchug inter-canyon area; $(\mathrm{x})$ Zhemchug Canyon; (+) Zhemchug-Pervenets inter-canyon area; (x) Pervenets Canyon; (+) Pervenets-Navarin inter-canyon area; (x) Navarin Canyon

Table 4. Results of quadratic discriminant function analyses using the physical and biota variables, where the model predicts group membership for each area. Bering-Pribilof, Pribilof-Zhemchung etc. are inter-canyon areas. CPUE: catch per unit effort

\begin{tabular}{|c|c|c|c|}
\hline & $\begin{array}{c}\text { Correct c. } \\
\text { Physical } \\
\text { characters } \\
(\%)\end{array}$ & $\begin{array}{l}\text { assification bas } \\
\text { Invertebrate } \\
\text { CPUE } \\
(\%)\end{array}$ & $\begin{array}{c}\text { sed on: } \\
\text { Fish } \\
\text { CPUE } \\
(\%)\end{array}$ \\
\hline \multicolumn{4}{|l|}{ Canyon comparisons } \\
\hline Inter-canyon slope & 81 & 94 & 80 \\
\hline Canyon & 89 & 14 & 68 \\
\hline \multicolumn{4}{|l|}{ Area comparisons } \\
\hline Bering Canyon & 99 & 4 & 68 \\
\hline Bering-Pribilof & 100 & 88 & 75 \\
\hline Pribilof Canyon & 100 & 27 & 50 \\
\hline Pribilof-Zhemchug & 100 & 4 & 51 \\
\hline Zhemchug Canyon & 95 & 4 & 41 \\
\hline Zhemchug-Pervenets & 99 & 15 & 59 \\
\hline Pervenets Canyon & 98 & 0 & 27 \\
\hline Pervenets-Navarin & 91 & 0 & 58 \\
\hline Navarin Canyon & 100 & 19 & 53 \\
\hline
\end{tabular}

(27-75\% correct classification) than for physical variables (91-100\%) (Table 4). Like the ANOSIM, the DFA result implies intermediate distinctiveness among the areas.
GAMs explained from $3 \%$ (for sleeper shark) to $86 \%$ (for giant grenadier) of the variance in the densities of the top 20 fish and crab species LCPUE (based on $\mathrm{R}^{2}$ values) (Table 5). For most of the species (17 of 20 ), over $50 \%$ of the variation in catches was explained by the GAMs (indicated by the $\mathrm{R}^{2}$ values in Table 5). Location and depth were significant variables for all species, and sediment size and sorting were significant variables for most species. Gradient was important for all of the rockfish and cod species, but not important for flatfish species. The densities of shallower species such as Pacific halibut and Pacific ocean perch generally dropped off at depths $>400 \mathrm{~m}$, while the densities of deeper species such as sablefish usually had a dome-shaped relationship with depth (Fig. 4). Where significant, density typically increased as temperature or current speed increased. Some species, such as Pacific grenadier, giant grenadier, shortspine thornyhead and tanner crab, occurred only on the slope, whereas other species, such as Pacific halibut, flathead sole and walleye pollock, occurred mostly on the outer shelf (Fig. 5).

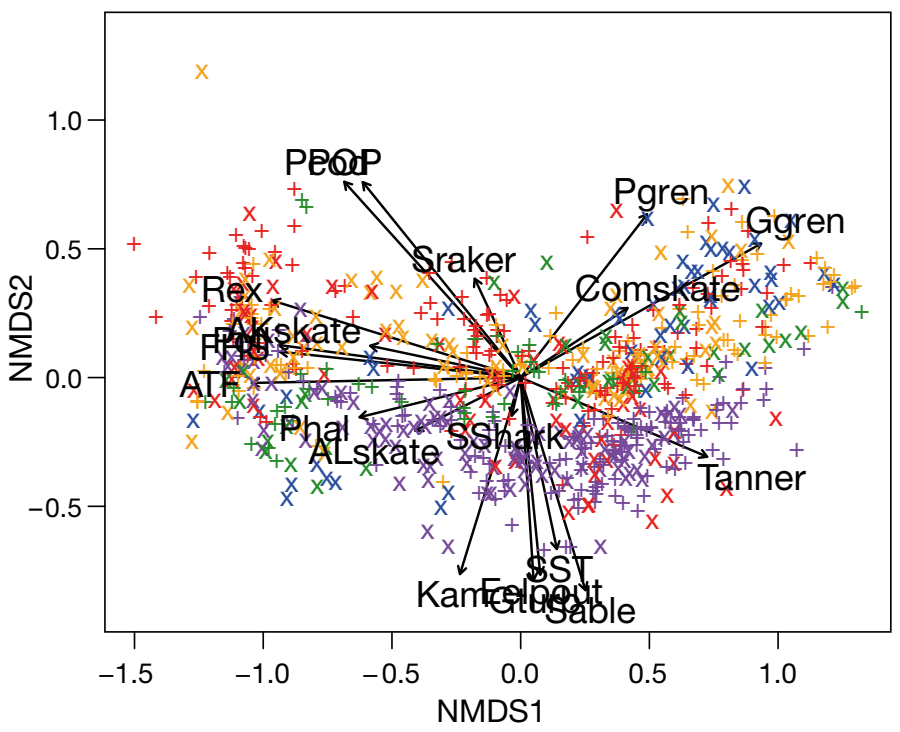

Fig. 3. Plot of major non-metric multidimensional scaling (NMDS) axes of fish and crab data. The variables are the top 20 fish and crab species (see Table 5). (x) Bering Canyon; (+) Bering-Pribilof intercanyon area; (x) Pribilof Canyon; (+) Pribilof-Zhemchug intercanyon area $(x)$ Zhemchug Canyon; $(+)$ Zhemchug-Pervenets inter-canyon area; (X) Pervenets Canyon; (+) Pervenets-Navarin inter-canyon area; (x) Navarin Canyon. AKskate: Alaska skate, ALskate: Aleutian skate, ATF: arrowtooth flounder, Kam: Kamchatka flounder, Gturb: Greenland turbot, Phal: Pacific halibut, FHS: flathead sole, SShark: sleeper shark, Sable: sablefish, Ggren: giant grenadier, Pgren: Pacific grenadier, Pcod: Pacific cod, Sraker: shortraker rockfish: POP: Pacific Ocean perch, Eelpout: two-line eelpout, Tanner: tanner crab, Poll: pollock, Comskate: Commander skate, Rex: rex sole, SST: shortspine thornyhead 
The GAM results for fish and crab species support the lack of clear distinctions among the 9 areas found in the NMDS, ANOSIM and DFA. Typically, species were distributed within several areas (i.e. not unique to 1 canyon) (Fig. 6). For example, Commander skate was found in all canyons as well as the slope between canyons. One species found mostly in the south of the study region (two-line eelpout) likewise was both within (Bering Canyon) and between (Bering-Pribilof) canyons. In addition, species occupied characteristic habitats related to habitats other than canyons: most flatfish and both cod species occurred primarily on the outer shelf; sablefish and shortspine thornyhead were more common southward (Fig. 6). Species common within a canyon were also common in the adjacent betweencanyon area, the 1 exception being Aleutian skate which were common in Bering and Pribilof canyons but not between these 2 canyons.

Most fish and crab GAMs (the exception was tanner crab) responded significantly (Table 5) to at least 2 of the 4 primary physical variables (depth, temperature, ocean productivity and current speed) that distinguished areas in the NMDS of the physical variables (Table 3 ). Temperature and ocean productivity were higher southward (Table 2), implying an influence of latitude. In addition, sediment size or sorting was significant in GAMs for most species (Table 5), implying an influence of sediment. The species distributions (Figs. 5 \& 6) imply that the statistically significant difference found for the ANOSIM is due to moderate differences in community composition among areas and not faunal distinctiveness of the 5 canyons. Instead the major characteristics structuring fish and crab communities appear to be depth, latitude and sediment rather than submarine canyons.

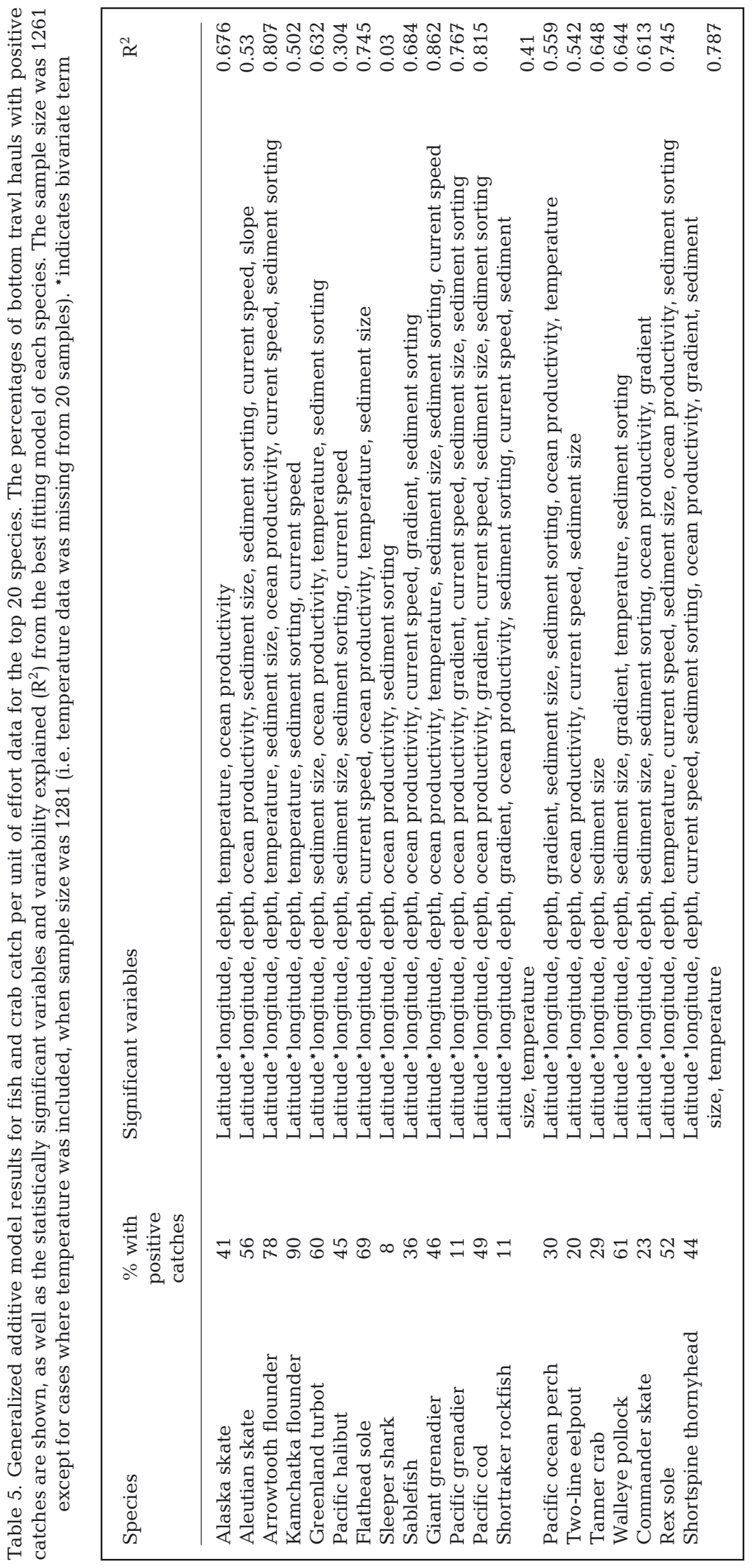




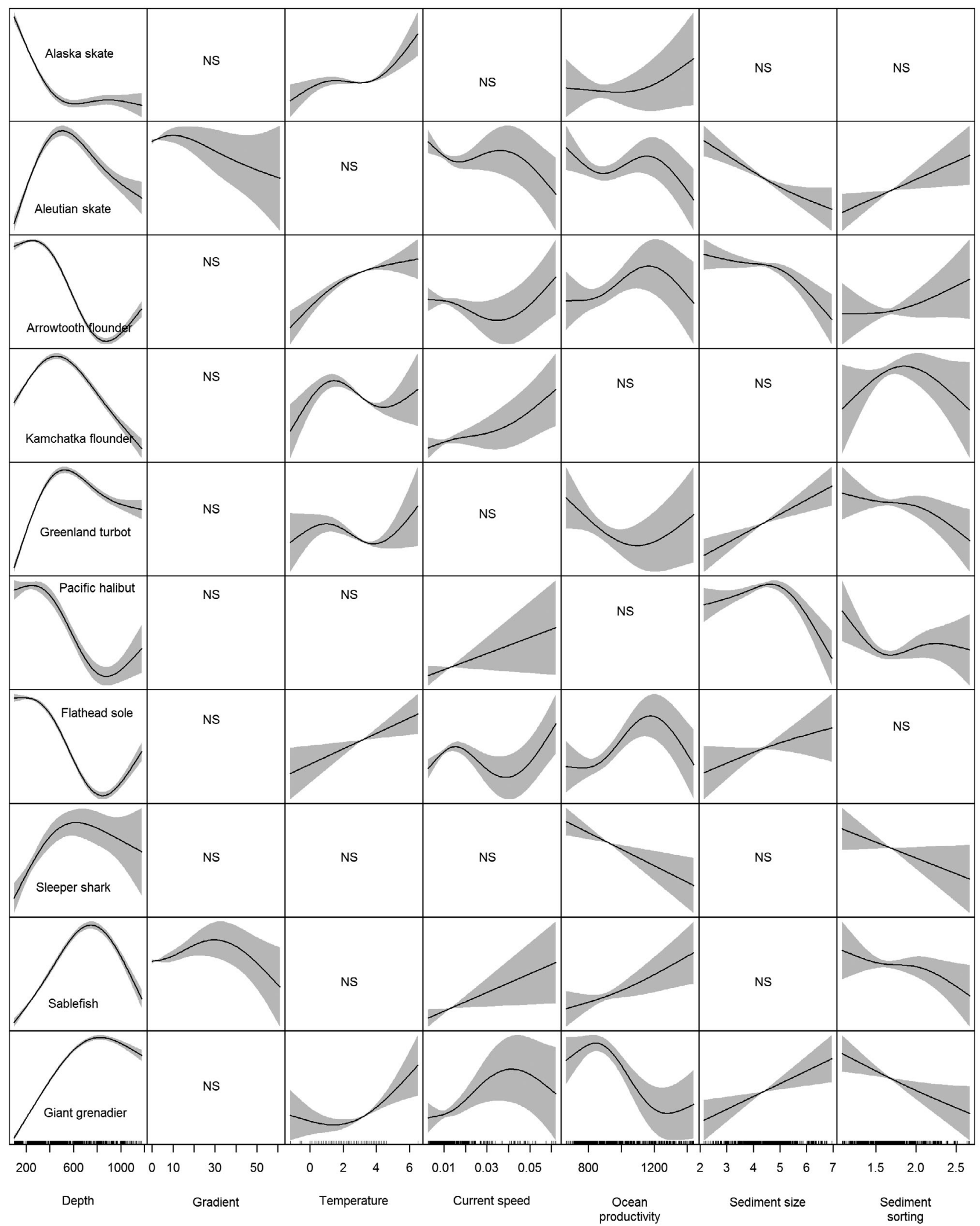

Fig. 4. Generalized additive model (GAM) fits for fish and crab species. The variables are depth (m), gradient (\%), temperature $\left({ }^{\circ} \mathrm{C}\right)$, current speed $\left(\mathrm{m} \mathrm{s}^{-1}\right)$, ocean productivity $\left(\mathrm{mg} \mathrm{C} \mathrm{d}^{-1} \mathrm{~m}^{-2}\right)$ and sediment size (phi) and sorting. POP: Pacific ocean perch; SST: shortspine thornyhead. NS indicates the variable was not significant in the best fitting model. Sediment sorting is the SD of mean grain size (phi) in each sediment sample 


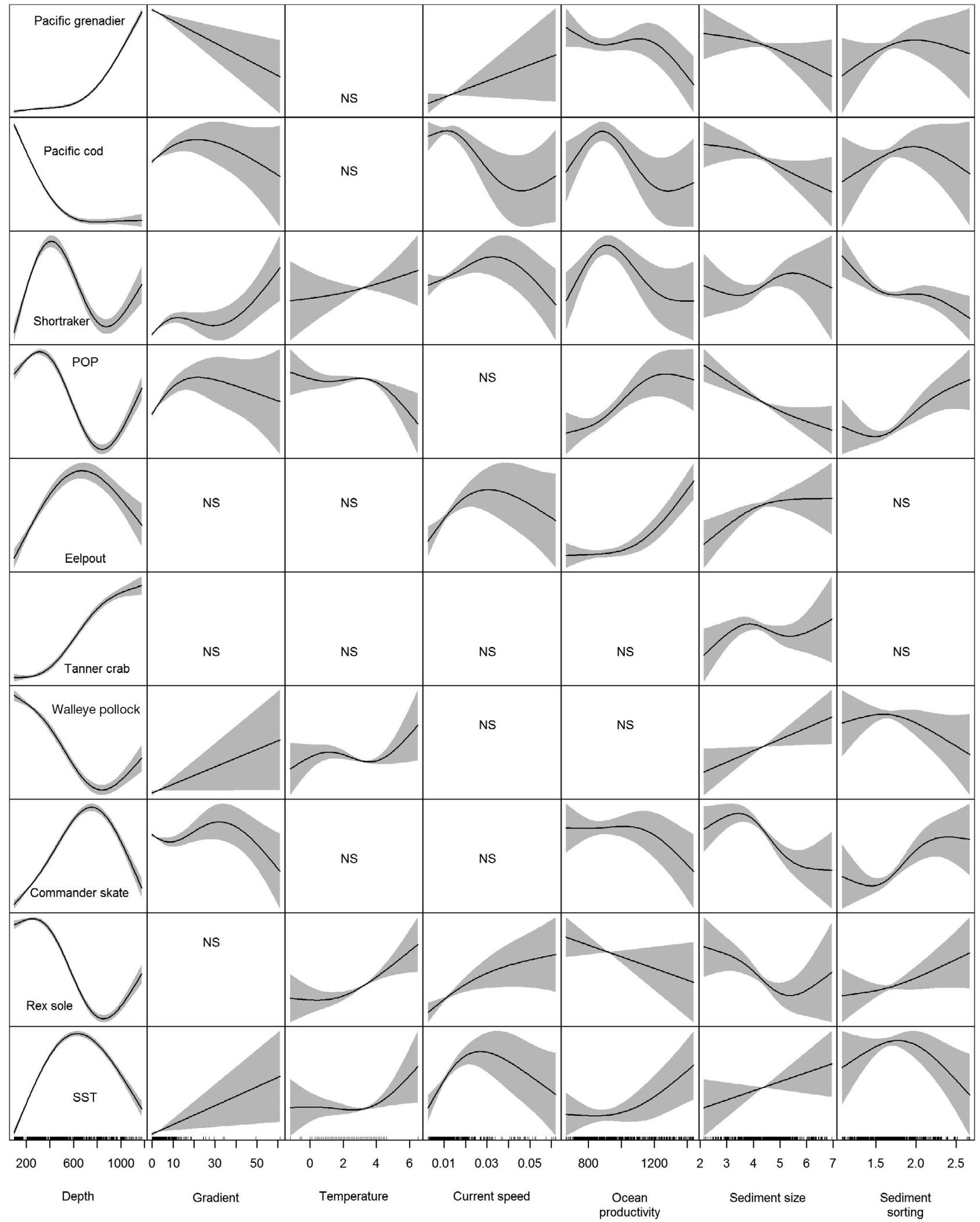

Fig. 4 (continued) 

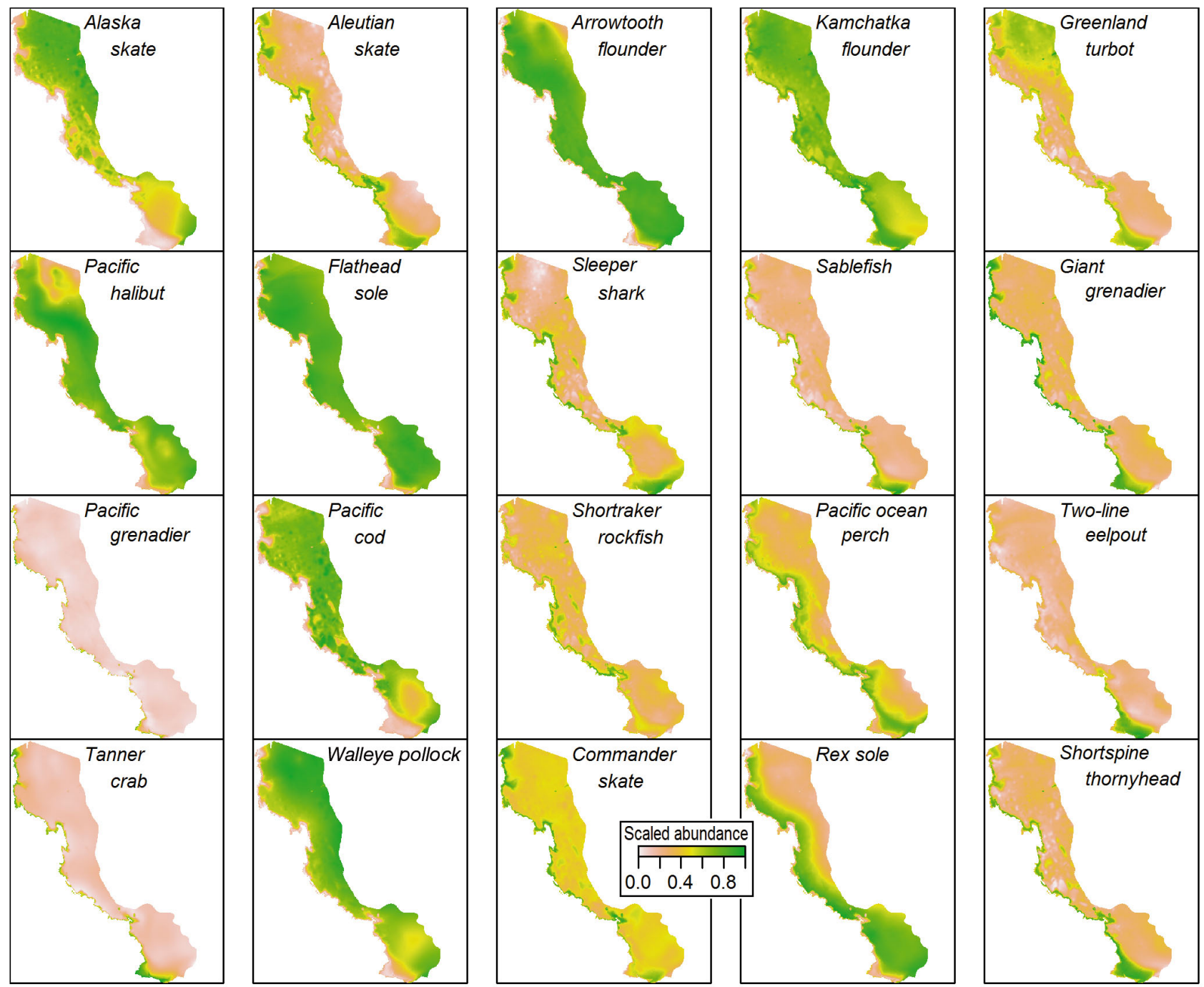

Fig. 5. Predicted spatial distributions of the top 20 fish and crab species (see Table 5) based on the generalized additive model (GAM). Density in weight $\left(\mathrm{kg} \mathrm{ha}^{-1}\right)$ on a scale of 0 to 1

The NMDS of the structure-forming invertebrates showed that the first NMDS axis was negatively correlated with Pennatulacea, which typically were shallower, and the second NMDS axis was positively correlated with Paragorgiidae, Plexauridae, Primnoidae, Isididae and Antipatharia and negatively correlated with Porifera (Table 3). The 9 areas overlapped in the NMDS plot (Fig. 7). The plotted points were concentrated along a line parallel to the second NMDS axis, which may have occurred because sponges were more common than corals and their cooccurrence was rare. The ANOSIM showed a statistically significant $(\mathrm{p}=0.001)$ but unsubstantial $(\mathrm{R}=$ 0.046) distinction among the 9 areas. The corresponding DFA also supported this conclusion; $88 \%$ of invertebrate samples for Bering-Pribilof were cor- rectly classified, but only because most (81\%) samples were classified into this 1 area (Table 4 ). In contrast, most samples for the other 8 areas were poorly classified (range $0-27 \%$ ). Thus, structure-forming benthic invertebrates at the taxonomic resolution used in this study were not useful in distinguishing individual areas.

The best-fitting GAMs of coral, sea whip and sponge explained $29-38 \%$ of deviance in presence-absence data (Table 6). The significant explanatory variables were location, depth, sediment sorting, and gradient (coral, sea whip, sponge), current speed, and ocean productivity (sea whip, sponge), and sediment size and temperature (sponge). Using threshold probabilities of 0.29 and 0.27 , the models correctly predicted coral and sea pen presence-absence 93 and $90 \%$ of 

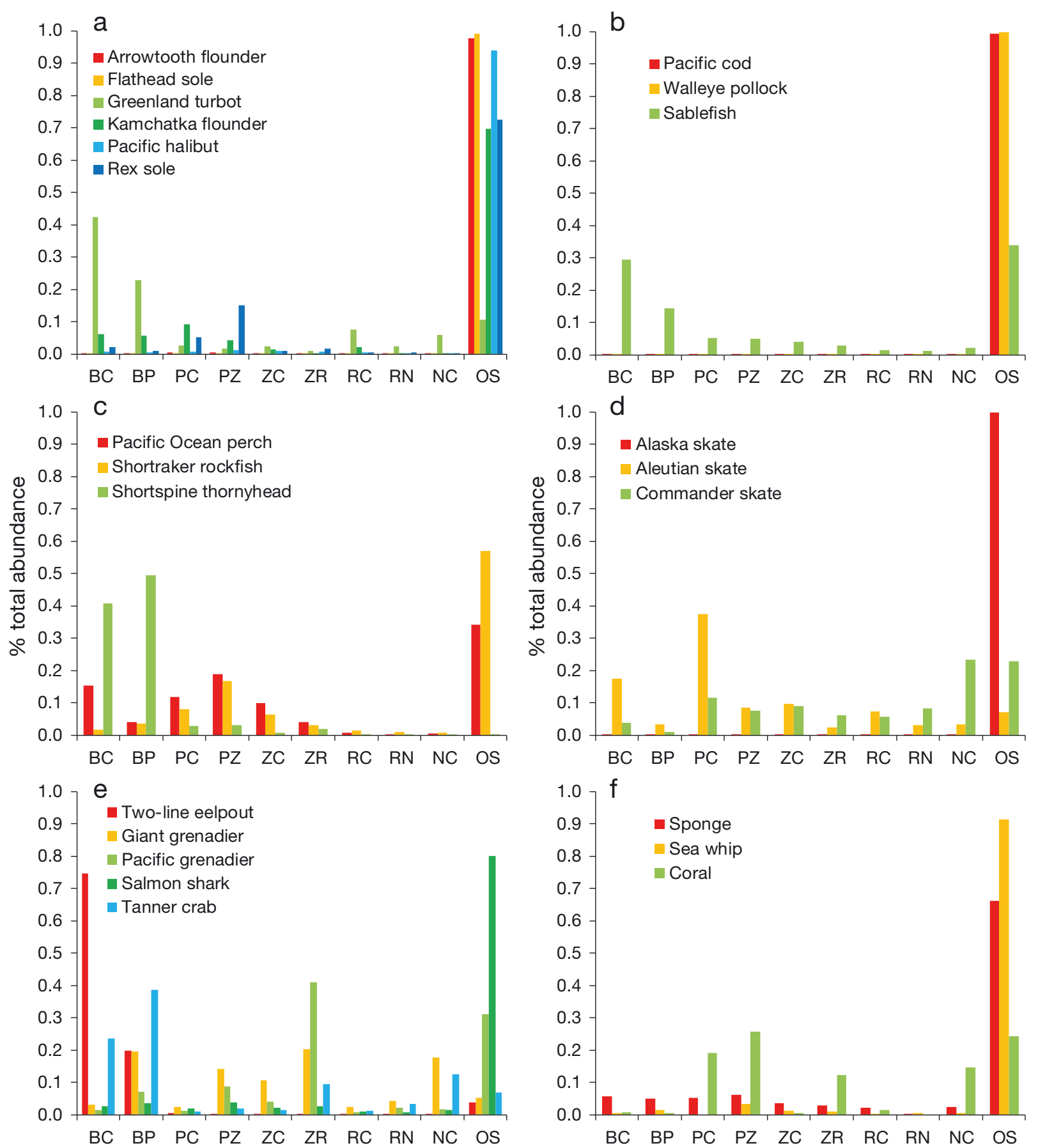

Fig. 6. Percentage of total abundance by area for (a) flatfish, (b) cods, (c) rockfish, (d) skates (e) other species and (f) structureforming benthic invertebrates. The areas are Bering Canyon (BC), Bering-Pribilof inter-canyon area (BP), Pribilof Canyon (PC), Pribilof-Zhemchug inter-canyon area (PZ), Zhemchug Canyon (ZC), Zhemchug-Pervenets inter-canyon area (ZR), Pervenets Canyon (RC), Pervenets-Navarin inter-canyon area (RN), Navarin Canyon (NC) and Outer shelf (OS).

the time, repectively (Table 6). Using a threshold probability of 0.53 , sponge presence-absence was correctly predicted $75 \%$ of the time. The AUC and the Kappa statistics indicated an acceptable predictive ability for these models. For coral, probability of presence increased with depth and decreased with in- creasing gradient (Fig. 8). For sea whips and sponge, the probability of presence decreased rapidly at depths over 200 and 650 m, respectively (Fig. 8).

Like the multivariate analysis for fish and crab species, the GAM results for coral, sea whip and sponge species (Fig. 9) match the lack of clear distinctions 


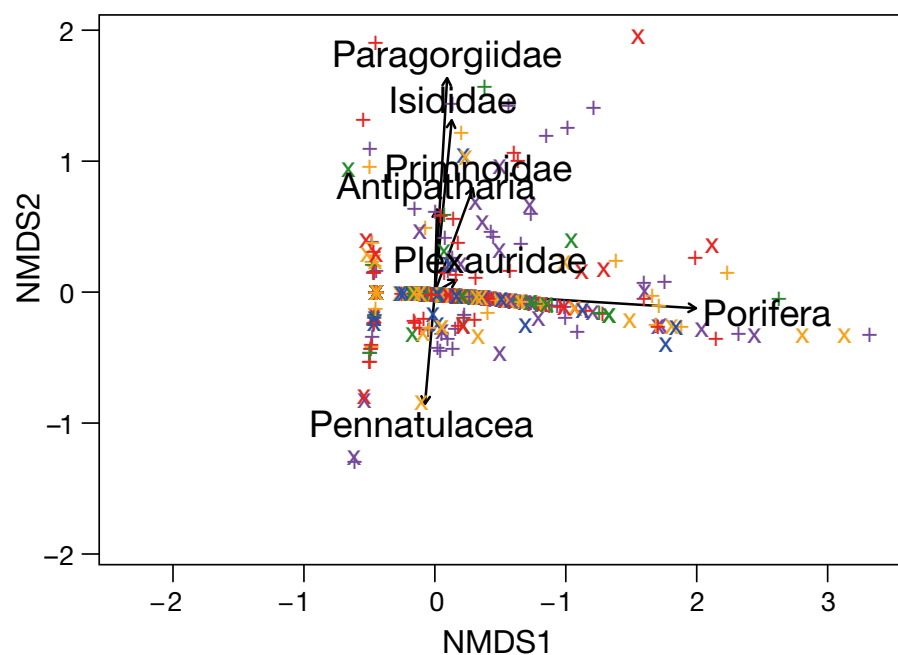

Fig. 7. Plots of major non-metric multidimensional scaling (NMDS) axes of structure-forming benthic invertebrate data. The variables are Plexauridae, Antipatharia, Primnoidae, Isididae and Paragorgiidae (corals), Pennatulacea (sea whips) and Porifera (sponges). (x) Bering Canyon; $(+)$ Bering-Pribilof inter-canyon area; (x) Pribilof Canyon $(+)$ Pribilof-Zhemchug inter-canyon area; $(x)$ Zhemchug Canyon; (+) Zhemchug-Pervenets inter-canyon area; ( $\mathrm{x}$ ) Pervenets Canyon; (+) Pervenets-Navarin inter-canyon area; (x) Navarin Canyon

among the 9 areas found in the NMDS, ANOSIM and DFA. For example, corals are predicted as probably present both within Pribilof Canyon as well as to the west of Pribilof Canyon (i.e. not unique to Pribilof Canyon). Likewise, sponges are predicted as probably present both within Zhemchug Canyon as well to the north and south of Zhemchug Canyon. The coral, sea whip and sponge GAMs responded significantly (Table 6) to at least one of the primary physical variables (depth, temperature, ocean productivity and current speed) that distinguished areas in the NMDS of the physical variables (Table 3). Only depth was significant for the coral GAM, but one other significant factor, sediment sorting, is correlated with sediment size and ocean productivity (Fig. 2), which were both significant factors in the coral GAM. The GAM plots of species distributions imply that the statistically significant difference found for the ANOSIM is due to minor differences, which matches the low R-value in the ANOSIM.

Predicted coral distribution was limited to the slope and shelf break, predicted sponge distribution occurred for both the slope and outer shelf, and predicted sea whip distribution was limited to the outer shelf (Fig. 9). More coral habitat was predicted for the slope $(76 \%)$ than the outer shelf $(24 \%)$; in contrast, $66 \%$ of sponge habitat and most (91\%) of

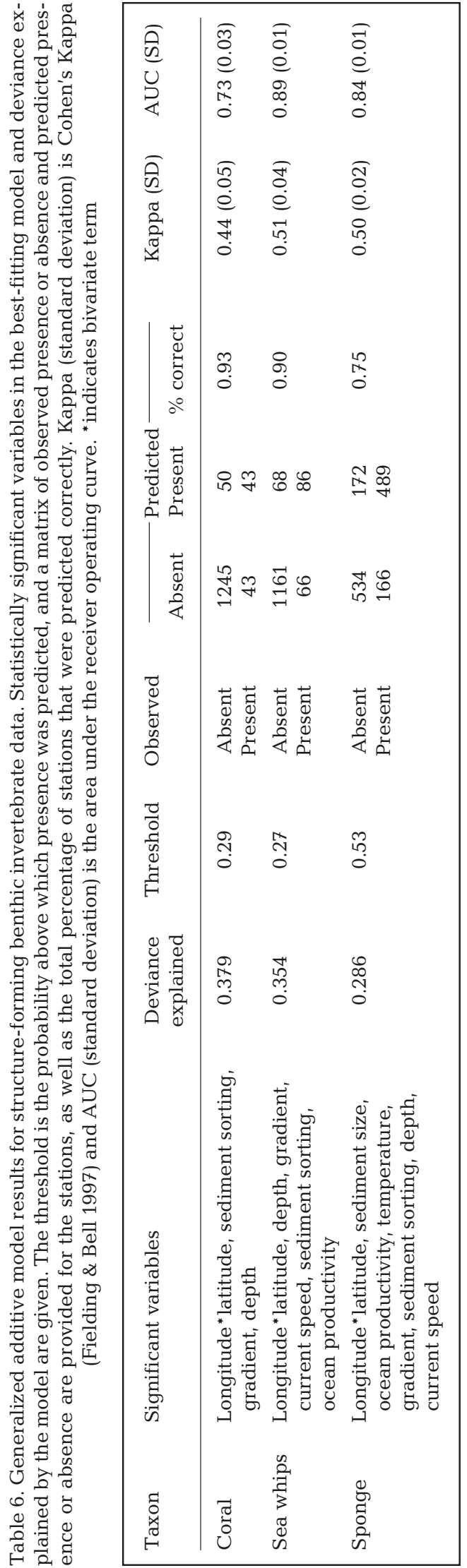




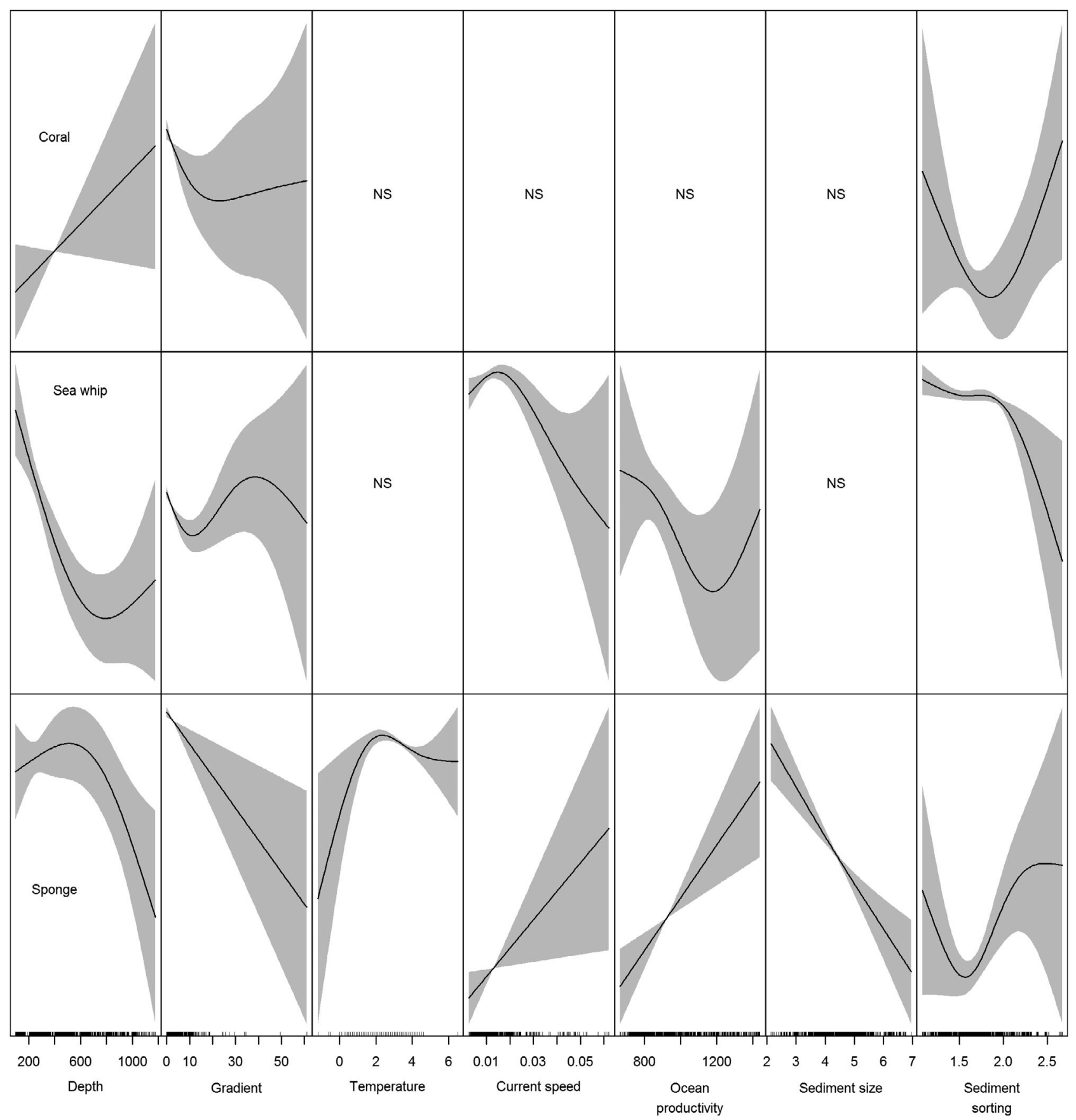

Fig. 8. Generalized additive model (GAM) fits for structure-forming benthic invertebrates. The variables are depth (m), gradient $(\%)$, temperature $\left({ }^{\circ} \mathrm{C}\right)$, current speed $\left(\mathrm{m} \mathrm{s}^{-1}\right)$, ocean productivity $\left(\mathrm{mg} \mathrm{C} \mathrm{d}^{-1} \mathrm{~m}^{-2}\right)$ and sediment size (phi) and sorting. NS indicates the variable was not significant in the best fitting model. Sediment sorting is the SD of mean grain size (phi) in each sediment sample

sea whip habitat was predicted for the outer shelf (Fig. 6). Considering only the slope, one notable feature is that $25 \%$ of the predicted coral habitat occurred in Pribilof Canyon, an area comprising only $10 \%$ of the total slope area; this area of predicted coral habitat extends westward into Pribilof-Zhemchug; together these 2 areas contain $60 \%$ of the predicted coral habitat on the slope. In contrast, only $1 \%$ of predicted coral habitat occurred in the other more rugged canyon, Zhemchug Canyon. 


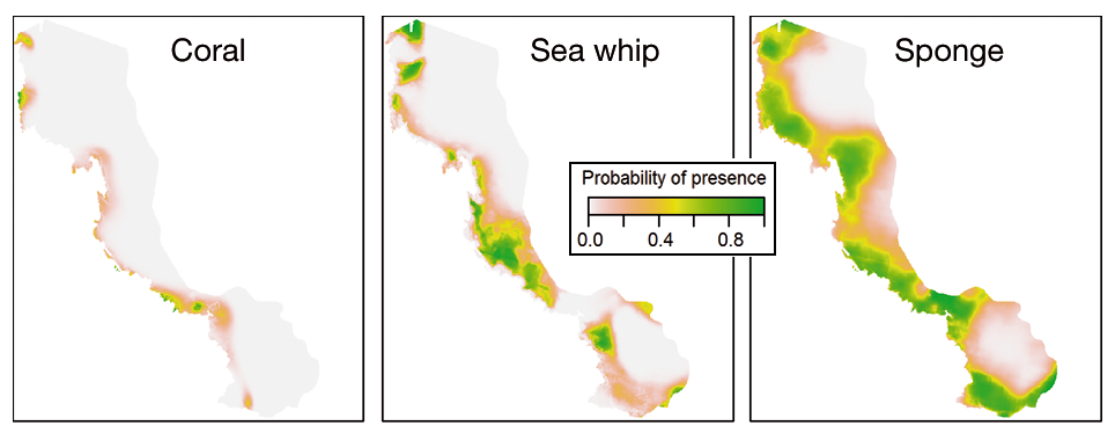

Fig. 9. Predicted spatial distributions of structure-forming benthic invertebrates based on the generalized additive model (GAM). Probability of presence on a scale of zero to one

\section{DISCUSSION}

\section{Validation of results}

Our primary sampling tool, the trawl survey gear, was able to sample nearly everywhere: Only $5 \%$ of slope habitat and none of the shelf habitat were classified by survey scientists as untrawlable during these surveys. In general, survey scientists described the untrawlable areas as 'too steep and bumpy' to trawl. Major untrawlable areas were found in Pribilof-Zhemchug (13\% of this area was untrawlable), Zhemchug Canyon (17\%), Zhemchug-Pervenets (1\%) and Pervenets-Navarin (8\%). The untrawlable area of Zhemchug Canyon extended $\sim 25 \mathrm{~km}$ along the shoreward side of this canyon. The untrawlable areas did not appear to substantially bias predictions of coral or sponge habitat, as these habitats were predicted to occur throughout the shoreward side of Zhemchug Canyon, whether sampled or not (Fig. 9).

The sediment information in our analyses lacked data on boulder and bedrock habitat, which is a potentially important limitation, given that any rock substrate that does occur provides potential habitat for rockfish, coral and sponge species. However, soft depositional substrates predominate and rock substrates are uncommon along the eastern Bering Sea slope and canyons (Scholl et al. 1968, Smith \& McConnaughey 1999); hence the lack of information on rock habitats may not be a major flaw. The information on untrawlable habitat also supports this conclusion. Areas may be untrawlable due to rock habitat as well as other factors such as steepness. The small amount of untrawlable habitat, as well as the fact that this habitat is usually classified as 'too steep and bumpy' rather than rocky, implies that the size of any rock habitat is small. Lastly, an underwater camera survey of the eastern Bering Sea slope was con- ducted during late summer 2014. When image analysis is complete in $\sim 1 \mathrm{yr}$, we will review our conclusion that rock habitat is limited on the eastern Bering Sea slope.

Another potential limitation of our results is that the bottom trawl surveys were designed to assess fish and crab populations in a standard fashion for use in fisheries stock assessments. As such, their effectiveness in sampling structure-forming invertebrates is unknown. However, since the bottom trawl surveys were carried out using rigorous standardized protocols (Stauffer 2004), the data should accurately reflect spatial distributions of structure-forming invertebrates. While net efficiency for these species is unknown, net efficiency is consistent across space and time and thus produces appropriate data for these analyses. Further support for this claim is the observation that structure-forming benthic invertebrates were frequently caught (frequency of occurrence for sponges: $57 \%$; for coral: $11 \%$; and for sea whips/sea pens: $7 \%$ ) in these surveys. Given the limitations of the sampling gear (low taxonomic resolution of structure-forming benthic invertebrates, unable to sample everywhere, as described in this and the previous 2 paragraphs), making definitive statements for structure-forming benthic invertebrates is difficult; however, our interpretation and conclusions are reasonable given the available evidence.

Two different survey trawls were used to collect the data that we analysed, one with roller gear and one without. The effect of this difference likely is minimal for the NMDS, ANOSIM and DFA which used only data from the slope, nearly all collected by the trawl with roller gear (>99\%). Some effect may have occurred for the GAM which used data from the slope and outer shelf, with $67 \%$ collected by the trawl with roller gear.

The GAM diagnostics such as prediction accuracies (which were high) imply satisfactory performance of this statistical model for predicting species distributions for structure-forming benthic invertebrates. Important habitat variables for distinguishing species distributions in the GAMs included depth, latitude and sediment for fish and crab as well as for structure-forming benthic invertebrates. These habitat variables were also among the primary physical variables distinguishing areas in the NMDS. These results imply that the GAMs reasonably represent 
distributions of structure-forming benthic invertebrates. One limitation is that the low numbers of individual corals, sponges and sea whips and the difficulty of identifying sponge species forced us to pool species into 3 general groups. The ecological requirements of individual species within these groups may differ and manifest as differences in their spatial distributions, which modeling general groups will mask.

Results from visual surveys generally match our predictions of coral and sponge distributions but not our predictions of sea whip distributions. We predicted coral presence (Fig. 8) primarily for slope habitat, which is in agreement with the results of Miller et al. (2012) who found that most coral were present at depths of 200-400 m. We predicted sponge presence (Fig. 9) in both slope and outer shelf habitat; Miller et al. (2012) found sponges to be most abundant at depths of $200-400 \mathrm{~m}$ but absent at 150-200 m. However, they may have missed sponges in outer shelf habitat because they sampled little there (only 77 video frames). We predicted sea whip presence primarily for the outer shelf adjacent to Zhemchug but not Pribilof Canyon (Fig. 9), whereas in 5 of 7 ROV deployments along the northwest edge of Pribilof Canyon, Brodeur (2001) reported areas containing dense aggregations of 1-2 $\mathrm{m}$ high sea whips Halipteris willemoesi evenly spaced $\sim 2 \mathrm{~m}$ apart over the depth interval of $185-240 \mathrm{~m}$. The issue is not low capture efficiency for sea whips because Brodeur (2001) reported that many sea whips were also collected using the trawl with roller gear deployed in the same area. Instead, the mismatch likely occurred for 2 reasons. First, trawl survey effort was minimal at $165-205 \mathrm{~m}$ in our study (only $0.5 \%$ of the total number of trawls) because only a few stations in the $37 \times 37 \mathrm{~km}$ grid (used in the 30 to $200 \mathrm{~m}$ survey) were located in this area. Second, Brodeur (2001) intentionally focused on an area of 'dense acoustic scattering of near-bottom fish' which he found was associated with dense aggregations of sea whips, whereas the trawl survey effort was conducted randomly or on a grid.

\section{Are submarine canyons faunally distinct features of the eastern Bering Sea slope?}

The 9 areas of the eastern Bering Sea slope exhibit distinguishing physical characteristics (Table 4), including some unique to canyons. The ocean is warmer and more productive southward (Table 2). Some canyons have a shallower gradient (e.g. Per- venets and Navarin canyons). Sediments are finer between canyons (values $>4$, indicating silt) than within canyons (values $<4$, indicating very fine sand). As for fauna, fish and crab densities show distinguishing characteristics for Bering Canyon and Bering-Pribilof, but are not unique to Bering Canyon (e.g. sablefish, eelpout are in general more common southward; Fig. 6). Bering Canyon and BeringPribilof may be differentiated from other areas based on fish and crab densities because of their location along the Aleutian Islands near Unimak Pass. Bering Canyon is an area of preferential transport onto the shelf (Stabeno et al. 1999). Unlike the other 4 canyons, the main axis of Bering Canyon is aligned with a major oceanic current, the Aleutian North Slope Current. Enhanced nutrient concentrations observed near and within Unimak Pass likely originate from Aleutian North Slope Current waters interacting with the topography of Bering Canyon and coming onto the shelf (Schumacher \& Stabeno 1998, Stabeno et al. 2002). Strong tidal currents crossing over the abrupt topography of Unimak Pass result in zones of vertical advection, mixing and surface convergences (Ladd et al. 2005) and also advect nutrient-rich water from Bering Canyon into Unimak Pass which mixes with water from the Gulf of Alaska; this enriched water exits Unimak Pass into the eastern Bering Sea (Stabeno et al. 2002). In addition, the shelf-slope boundary typically lies at $\sim 200 \mathrm{~m}$ in the eastern Bering Sea except for the northern edge of Bering Canyon and some of the Bering-Pribilof shelf break which lie at $\sim 500 \mathrm{~m}$. Because depth is a major factor structuring fish and crab communities, the difference in depth range between Bering Canyon and Bering-Pribilof is likely also one of the reasons for the differences in these communities in these areas.

The major characteristics structuring fish and invertebrate communities were depth, latitude and sediment rather than submarine canyons. In the GAMs for fish and crab species, location and depth were significant variables for all species and sediment size or sorting were significant variables for most species (Table 5); for structure-forming invertebrates, significant variables included location, depth or temperature (which are inversely correlated) and sediment size or sorting (Table 6). In addition, species were affiliated with habitats not specific to canyons: most flatfish and both cod species occurred primarily on the outer shelf, as did sea whips; sablefish and eelpout were more common southward (Fig. 7); corals were more common at greater depths (Fig. 8). The one exception to canyon non-exclusivity is the Aleutian skate, which were most common 
in Bering and Pribilof canyons (Fig. 6), which are known as nursery sites for skates (Hoff 2010).

One notable characteristic of the canyons is that about one quarter of the coral habitat predicted for the eastern Bering Sea slope occurs in Pribilof Canyon, an area that comprises only $\sim 10 \%$ of the total slope area (Fig. 6). This area of predicted coral habitat also extends westward to the adjacent slope, indicating that this coral habitat concentration is not unique to Pribilof Canyon but rather that it is typical for a larger area (Pribilof Canyon and westward). Together these 2 areas contain $60 \%$ of the predicted coral habitat on the slope. In contrast, only $1 \%$ of predicted coral habitat occurred in the other more rugged canyon, Zhemchug Canyon. Coral habitat may concentrate in Pribilof Canyon and westward because preferential transport onto the shelf has been observed west of the Pribilof Islands (Stabeno et al. 1999). West of the Pribilof Islands, the outer shelf narrows south of St. George Island (Fig. 1), accelerating the flow, which then turns northward, becomes shallower and parallels the $100 \mathrm{~m}$ contour west of the Pribilof Islands (Stabeno et al. 2008). Higher currents here may favor survival and growth of coral, which rely on currents to bring them food.

There is currently no evidence of many endemic or rare species for the eastern Bering Sea slope. Eighteen coral taxa are known for the eastern Bering Sea (R. P. Stone unpubl. data). None are endemic to the region or particularly rare and some range as far south as Washington State. The eastern Bering Sea is the northern extent of the range for most of these species so some taxa are uncommon. There are 67 sponge taxa reported for the eastern Bering Sea (Stone et al. 2011). Of these, a single undescribed hexactinellid sponge (R. P. Stone unpubl. data) and a relatively abundant, recently described demosponge Aaptos kanuxx (Lehnert et al. 2008) are known only from Pribilof Canyon. These 2 taxa may be endemic to the region. Other than these, the sponge fauna are distributed widely, with strong biogeographical affinities to neighboring regions including the Arctic Ocean (Stone et al. 2011). In contrast, the Aleutian Islands have at least 40 endemic species of corals (Stone 2014, R. P. Stone unpubl. data) and 35 endemic species of sponges (Stone et al. 2011, Lehnert \& Stone 2013, Lehnert et al. 2013) known to date.

On the order of $15 \%$ of canyons globally may support deep-sea biomass hotspots (De Leo et al. 2010). Our findings indicate that eastern Bering Sea canyons are not among those locations; for example, fish and crab densities for most of these canyons are not clearly distinguishable from those for the adja- cent slope. De Leo et al. (2010) described 3 factors for identifying high productivity canyons: (1) heads positioned in coastal embayments with high loads of terrestrial material; (2) U-shaped canyon cross sections, and (3) substantial inputs of coastal sediments. None of these factors occur for eastern Bering Sea canyons, with the exception of Bering Canyon which preferentially receives on-shelf transport and occurs adjacent to oceanic passes where nutrients and productivity are enhanced. For the remaining eastern Bering Sea canyons, while coastal effects are unlikely, eddies in the Bering Sea Current may concentrate primary and secondary production. We did not detect a distinguishing effect on their fauna, indicating that any effect is minor.

Acknowledgements. We thank Steve Lewis, NOAA's Alaska Regional Office, for providing bathymetric information; $\mathrm{Al}$ Hermann, NOAA's Pacific Marine Environmental Laboratory, for providing the model-based estimates of ocean currents; Carla J. Moore, NOAA's National Geophysical Data Center, for providing the sediment data; and John Hocevar, Greenpeace, for providing visual survey data of Pribilof and Zhemchug canyons. We thank Gary Greene, Moss Landing Marine Laboratory; and Dave Scholl, US Geological Survey, for advice on canyon definitions. We also thank Jon Heifetz, Carol Ladd, Bob Lauth, Ivan Mateo and Paul Spencer and 2 anonymous reviewers for their reviews and useful comments. The findings and conclusions in the paper are those of the authors and do not necessarily represent the views of the National Marine Fisheries Service, NOAA. Reference to trade names does not imply endorsement by the National Marine Fisheries Service, NOAA.

\section{LITERATURE CITED}

Auster PJ, Gjerde K, Heupel E, Watling L, Grehan A, Rogers AD (2011) Definition and detection of vulnerable marine ecosystems on the high seas: problems with the 'moveon' rule. ICES J Mar Sci 68:254-264

> Bacheler NM, Ciannelli L, Bailey KM, Duffy-Anderson JT (2010) Spatial and temporal patterns of walleye pollock (Theragra chalcogramma) spawning in the eastern Bering Sea inferred from egg and larval distributions. Fish Oceanogr 19:107-120

Bacheler NM, Ciannelli L, Bailey KM, Bartolino V (2012) Do walleye pollock exhibit flexibility in where or when they spawn based on variability in water temperature? Deep Sea Res II 65-70:208-216

Behrenfeld MJ, Falkowski PG (1997) Photosynthetic rates derived from satellite-based chlorophyll concentration. Limnol Oceanogr 42:1-20

Brodeur RD (2001) Habitat-specific distribution of Pacific ocean perch (Sebastes alutus) in Pribilof Canyon, Bering Sea. Cont Shelf Res 21:207-224

> Clarke KR (1993) Non-parametric multivariate analyses of changes in community structure. Aust J Ecol 18:117-143

$>$ Clement Kinney J, Maslowski W, Okkonen S (2009) On the processes controlling shelf-basin exchange and outer shelf dynamics in the Bering Sea. Deep-Sea Res II 56: 
$1351-1362$

Coachman LK (1986) Circulation, water masses and fluxes on the southeastern Bering Sea shelf. Cont Shelf Res 5: 23-108

> Danielson S, Curchitser E, Hedstrom K, Weingartner T, Stabeno P (2011) On ocean and sea ice modes of variability in the Bering Sea. J Geophys Res 116:C12034. doi:10.1029/2011JC007389

> Danielson S, Hedstrom K, Aagaard K, Weingartner T, Curchitser E (2012) Wind-induced reorganization of the Bering shelf circulation. Geophys Res Lett 39:L 08601. doi: 10.1029/2012GL051231

> De Leo FC, Smith CR, Rowden AA, Bowden DA, Clark MR (2010) Submarine canyons: hotspots of benthic biomass and productivity in the deep sea. Proc R Soc B 277: 2783-2792

ESRI (2009) ArcGIS Desktop: Release 9. Environmental Systems Research Institute, Redlands, CA

Fielding AH, Bell JF (1997) A review of methods for the assessment of prediction errors in conservation presence/absence models. Environ Conserv 24:38-49

- Harris PT, Whiteway T (2011) Global distribution of large submarine canyons: geomorphic differences between active and passive continental margins. Mar Geol 285: 69-86

Hastie T, Tibshirani R (1990) Generalized additive models. Chapman \& Hall/CRC, Boca Raton, FL

Hickey BM (1995) Coastal submarine canyons. Topographic effects in the ocean. SOEST Spec Publ 95-110, University of Hawaii, Manoa

Hoff GR (2010) Identification of skate nursery habitat in the eastern Bering Sea. Mar Ecol Prog Ser 403:243-254

Hoff GR, Britt LL (2013) Results of the 2012 eastern Bering Sea upper continental slope survey of groundfish and invertebrate resources. NOAA Tech Memo NMFS-AFSC258

Hosmer DW, Lemeshow S (2004) Applied logistic regression, 2nd edn. John Wiley \& Sons, Hoboken, NJ

Karl HA, Carlson PR, Gardner JV (1996) Aleutian Basin of the Bering Sea: styles of sedimentation and canyon development. In: Gardner JF, Field ME, Twichell DC (eds) Geology of the United States seafloor: the view from GLORIA. Press Syndicate of the University of Chicago, Chicago, IL

Kenchington E, Lirette C, Cogswell A, Archambault D and others (2010) Delineating coral and sponge concentrations in the biogeographic regions of the east coast of Canada using spatial analyses. DFO Can Sci Advis Sec Res Doc 2010/041

Kenchington E, Power D, Koen-Alonso M (2013) Associations of demersal fish with sponge grounds on the continental slopes of the northwest Atlantic. Mar Ecol Prog Ser 477:217-230

Knudby A, Kenchington E, Murillo FJ (2013) Modeling the distribution of Geodia sponges and sponge grounds in the Northwest Atlantic. PLoS ONE 8:e82306

Ladd C, Jahncke J, Hunt GL, Coyle KO, Stabeno PJ (2005) Hydrographic features and seabird foraging in Aleutian Passes. Fish Oceanogr 14:178-195

Ladd C, Stabeno PJ, O'Hern JE (2012) Observations of a Pribilof eddy. Deep-Sea Res I 66:67-76

Lauth RR (2013) Results of the 2012 eastern and northern Bering Sea continental shelf bottom trawl survey of groundfish and invertebrate fauna. NOAA Tech Memo NMFS-AFSC-256
Lehnert H, Stone RP (2013) Four new species of Haplosclerida (Porifera, Demospongiae) from the Aleutian Islands, Alaska. Zootaxa 3700:573-582

Lehnert H, Hocevar J, Stone RP (2008) A new species of Aaptos (Porifera, Hadromerida, Suberitidae) from Pribilof Canyon, Bering Sea, Alaska. Zootaxa 1939:65-68

Lehnert H, Stone RP, Drumm D (2013) Geodia starki sp. nov. (Porifera, Demospongiae, Astrophorida) from the Aleutian Islands, Alaska, USA. J Mar Biol Assoc UK 94: 261-265

Miller RJ, Hocevar J, Stone RP, Fedorov DV (2012) Structure-forming corals and sponges and their use as fish habitat in Bering Sea submarine canyons. PLoS ONE 7:e33885

> Mortensen PB, Buhl-Mortensen L, Gebruk AV, Krylova EM (2008) Occurrence of deep-water corals on the MidAtlantic Ridge based on MAR-ECO data. Deep-Sea Res II 55:142-152

Murillo FJ, Muñoz PD, Cristobo J, Ríos P, González C, Kenchington E, Serrano A (2012) Deep-sea sponge grounds of the Flemish Cap, Flemish Pass and the Grand Banks of Newfoundland (Northwest Atlantic Ocean): distribution and species composition. Mar Biol Res 8: 842-854

Normarck WR, Carlson PR (2003) Giant submarine canyons: Is size any clue to their importance in the rock record? Geol Soc Am Spec Pap 370:175-190

Oksanen JF, Blanchet G, Kindt R, Legendre P and others (2013) vegan: Community Ecology Package. R package version 2.0-6. http://CRAN.R-project.org/package=vegan

R Core Team (2013) R: a language and environment for statistical computing. R Foundation for Statistical Computing, Vienna. www.R-project.org/

Rooper CN, Hoff GR, De Robertis A (2010) Assessing habitat utilization and rockfish (Sebastes sp.) biomass in an isolated rocky ridge using acoustics and stereo image analysis. Can J Fish Aquat Sci 67:1658-1670

> Rooper CN, Zimmermann M, Prescott M, Hermann A (2014) Predictive models of coral and sponge distribution, abundance and diversity in bottom trawl surveys of the Aleutian Islands, Alaska. Mar Ecol Prog Ser 503:157-176

- Ross RE, Howell KL (2013) Use of predictive habitat modelling to assess the distribution and extent of the current protection of 'listed' deep-sea habitats. Divers Distrib 19:433-445

Scholl DW, Buffington EC, Hopkins DM (1968) Geologic history of the continental margin of North America in the Bering Sea. Mar Geol 6:297-330

Schumacher JD, Reed RK (1992) Characteristics of currents over the continental slope of the eastern Bering Sea. J Geophys Res 97:9423-9433

Schumacher JD, Stabeno PJ (1994) Ubiquitous eddies of the eastern Bering Sea and their coincidence with concentrations of larval pollock. Fish Oceanogr 3:182-190

Schumacher JD, Stabeno PJ (1998) The continental shelf of the Bering Sea. In: Robinson AR, Brink KH (eds) The sea: the global coastal ocean regional studies and synthesis, Vol. XI. John Wiley \& Sons, New York, NY, p 869-909

Smith KR, McConnaughey RA (1999) Surficial sediments of the eastern Bering Sea continental shelf: EBSSED database documentation. NOAA Tech Memo NMFS-AFSC104

Springer AM, McRoy CP, Flint MV (1996) The Bering Sea Green Belt: shelf-edge processes and ecosystem production. Fish Oceanogr 5:205-223 
Stabeno PJ, Schumacher JD, Ohtani K (1999) The physical oceanography of the Bering Sea. In: Loughlin TR, Ohtani $\mathrm{K}$ (eds) Dynamics of the Bering Sea: a summary of physical, chemical, and biological characteristics, and a synopsis of research on the Bering Sea. University of Alaska Sea Grant AK-SG-99-03, North Pacific Marine Science Organization (PICES), Fairbanks, AK, p 1-28

Stabeno PJ, Reed RK, Napp JM (2002) Transport through Unimak Pass, Alaska. Deep-Sea Res II 49:5919-5930

Stabeno PJ, Kachel N, Mordy C, Righi D, Salo S (2008) An examination of the physical variability around the Pribilof Islands in 2004. Deep-Sea Res II 55:1701-1716

Stauffer G (compiler) (2004) NOAA protocols for groundfish bottom trawl surveys of the nation's fishery resources. NOAA Tech Memo NMFS-F/SPO-65

Stone RP (2014) The ecology of deep-sea coral and sponge habitats of the central Aleutian Islands of Alaska. NOAA

Editorial responsibility: Romuald Lipcius,

Gloucester Point, Virginia, USA
Prof Paper NMFS 16. http://spo.nmfs.noaa.gov/pp16.pdf Stone RP, Lehnert H, Reiswig H (2011) A guide to the deepwater sponges of the Aleutian Island Archipelago. NOAA Prof Paper NMFS 12. http://spo.nmfs.noaa.gov/pp12.pdf Venables WN, Ripley BD (2002) Modern applied statistics with S. Springer, New York, NY

- Wassenberg TJ, Dews G, Cook SD (2002) The impact of fish trawls on megabenthos (sponges) on the north-west shelf of Australia. Fish Res 58:141-151

Wood SN (2006) Generalized additive models: an introduction with R. Chapman \& Hall, Boca Raton, FL

> Woodby D, Carlile D, Hulbert L (2009) Predictive modeling of coral distribution in the Central Aleutian Islands, USA. Mar Ecol Prog Ser 397:227-240

Zuur AF, Leno EN, Walker NJ, Saveliev AA, Smith GM (2009) Mixed effects models and extensions in ecology with R. Springer Verlag, New York, NY

Submitted: July 14, 2014; Accepted: January 12, 2015 Proofs received from author(s): April 1, 2015 